\title{
A VIS
}

Le Tome $X X I I$ des Travaux de l'Association internationale de Géodésie relatif à l'Assemblée générale de I'U.G.G.I. tenue à Berkeley en avril 1963 vient de paraitre.

$$
\text { Il est vendu par le Bureau central de I'A.I.G. } 19 \text { Rue Auber }
$$
au prix de 21 franes. 